\title{
Barbie y la "fridazación" en el contexto de las industrias culturales
}

Barbie and "fridazation" in cultural industries context

ARACELI BARBOSA*

Universidad Autónoma del Estado de Morelos

México

* araceli_barbosa@uaem.mx

iD https://orcid.org/0000-0001-8787-439X

Artículo de investigación

Recepción: 29 de Julio de 2020

Aprobación: 02 de Septiembre 2020

Cómo citar este artículo:

Barbosa, A. (2020). Barbie y la "fridazación" en el contexto de las industrias culturales. Designio. Investigación en diseño gráfico y estudios de la imagen, 2(1), pp. 114-143. Recuperado a partir de: http://cipres.sanmateo.edu.co/index.php/designio

Reconocimiento-SinObraDerivada 4.0 Internacional (CC BY-NC-ND) 


\section{Resumen:}

En el presente artículo se plantea la forma en que la juguetera estadounidense Mattel, Inc. tergiversa y deconstruye la imagen de la artista mexicana Frida Kahlo, al fetichizarla y trastocar su identidad mediante la comercialización de la muñeca Barbie. En el contexto de las industrias culturales, se analiza cómo las lógicas capitalistas banalizan el arte y la cultura al reducirlos a un uso instrumental. De este modo, los bienes culturales se "fetichizan" mediante la producción en serie de todo tipo de mercancías industriales destinadas al consumo masivo. Inmersas en la alienación del consumo, las masas se alinean a los intereses comerciales de las megaempresas transnacionales a partir del consumo de sus marcas globales. Inscrita en la industria cultural del juguete, Mattel, Inc. ha desarrollado estrategias de marketing globales, camufladas de cultura y género para promover a su muñeca. En esta perspectiva, la juguetera también ha logrado penetrar en el campo del arte posicionando la imagen de Barbie como insumo simbólico de la cultura pop.

Palabras clave: Barbie; fridazación; imagen; industrias culturales; arte.

\section{Abstract:}

The question is raised about how the American toy maker Mattel, Inc. distorts and deconstructs the image of Mexican artist Frida Kahlo, by fetishizing her and disrupting her identity through the marketing of the Barbie doll. In the context of the cultural industries, there is analysis of how capitalist logics trivialize art and culture by reducing them to instrumental use. In this way, cultural goods are fetishized through the mass production of all kinds of industrial goods aimed at mass consumption. Immersed in the alienation of consumption, the masses align themselves with the commercial interests of transnational mega-companies by consuming their global brands. Registered in the cultural toy industry, Mattel, Inc. has developed global marketing strategies, camouflaged by culture and gender, to promote its doll. In this perspective, the toy maker has also managed to penetrate the field of art by placing the image of Barbie as a symbolic input of pop culture.

Keywords: Barbie; fridazation; image; cultural industries; art. 


\section{6 \\ Introducción}

Desde su aparición en el Salón del juguete de Nueva York, en 1959, la muñeca Barbie de la marca estadounidense Mattel, Inc. se convirtió en unéxito deventas sin precedentes de la industria juguetera. Éxito global que se mantiene vigente, ya que se estima que cada tres (3) segundos se vende un ejemplar de este juguete en el mundo (Marciales, 2019). Su repercusión en el ámbito cultural ha sido tal, que incluso el Diccionario de la lengua española la define como una muñeca que representa a la mujer joven estilizada y atractiva.

Efectivamente, Barbie connota el ideal estético de raza y feminidad, valores de género, de la cultura occidental. La globalización de este estereotipo de mujer ha sido el resultado de agresivas campañas publicitarias que Mattel, Inc. ha utilizado para mantener la permanencia de su juguete en el mercado, adaptándola a los imperativos culturales de cada época. En el siglo XXI ha promovido la imagen de la muñeca como portadora de los ideales de género — resultado de las luchas feministas-que, desde principios de la década de los s del siglo XX, cuestionaron la cosificación de la mujer, el uso instrumental de su cuerpo y sexualidad, la sexualización de la imagen femenina, la enajenación narcisista, entre otras cosas.

No obstante, Barbie representa en esencia la degradación de la mujer que proyecta el modelo de feminidad hasta antes de la lucha feminista. Ahora, la juguetera la presenta como promotora de la diversidad cultural e inclusión, opuesta a toda clase de discriminación. Se emplean estrategias de marketing que también muestran nuevos diseños cuyo objetivo es generar empatía, ya que la muñeca puede aparecer sin cabello, con vitíligo, con prótesis en las extremidades o en silla de ruedas.

En este contexto, resultan incongruentes las campañas publicitarias denominadas Sheroes e Inspiring Women, lanzadas en el 2015 y 2018, respectivamente, con el objetivo de promover las ventas de la muñeca. Pretendieron emular a las mujeres del pasado y del presente que por sus méritos intelectuales, artísticos o atléticos han sobresalido en sus distintos ámbitos. Bajo este propósito, una de las mujeres seleccionada por la compañía Mattel, Inc. fue la artista mexicana Frida Kahlo. Sin embargo, resulta evidente la cualidad artificiosa de esta estrategia mercadotécnica si se toma en cuenta la carga simbólica, cultural y de género que históricamente ha proyectado Barbie.

En esta perspectiva, el papel que juegan las industrias culturales es analizado con el fin de evidenciarlos mecanismos que intervienen en el proceso de convertir los bienes culturales en fetiches de producción estandarizada para ser comercializados en función 
del consumo masivo. De este modo, se puede apreciar la forma en que Mattel, Inc. ha desarrollado sus estrategias mercantilistas, utilizando los medios de comunicación masiva, en tanto constituyentes del mismo sistema de las industrias culturales. Devienen concomitantes, ya que su función es influir en la cultura de masas, los valores, gustos, estereotipos, ideologías, determinadas por la cultura dominante. En suma, el aparato publicitario a su servicio es el que opera en la alienación de la subjetividad de las masas.

\section{Barbie y el femvertising}

En el año 2015 la juguetera estadounidense Mattel, Inc. creó la campaña publicitaria denominada Sheroes con el objetivo de "rendir homenaje" a las mujeres ejemplares del pasado y del presente; asimismo, en 2018 lanzó la serie Inspiring Women para "adultos coleccionistas" con la que se pretendió representara la pintora mexicana Frida Khalo, lo cual ha levantado voces de crítica entre intelectualesy artistas en contra de este juguete(Webmaster, 2018). Esta polémica resulta comprensible si se toma en cuenta que la muñeca posee una carga simbólica cultural que connota el estereotipo de mujer idealizada por los valores de género de la cultura patriarcal hegemónica: el de una fémina de "raza blanca".

La feminidad que proyecta la muñeca obedece a la de una mujer narcisista, enajenada por el culto a la personalidad, así como del consumismo del american way of life. El cuerpo y la apariencia se transforman en el leitmotiv de la razón de ser. De ahí que su imagen con el rostro de Frida resulte antitético; el solo hecho de intentar asimilarla significa una táctica de marketing que la juguetera ha ideado con el afán de incrementar sus ventas, empleando el femvertising como ardid publicitario que pretende pasar por propaganda con perspectiva de género.

De hecho, el diseño de la muñeca "Frida" ni siquiera alude a las características fenotípicas de la artista, como color de ojos, entrecejo abundante o bozo — vello facial arriba de la boca-. Al contrario, el diseño de Kelley Lindberg la presenta con facciones afiladas, ojos claros, cejas poco pobladas, labios gruesos, sin bozo, brazos y piernas extremadamente largos, en realidad es una Barbie disfrazada de Frida. 


\section{8}

Figura 1. Barbie-Frida (2018)

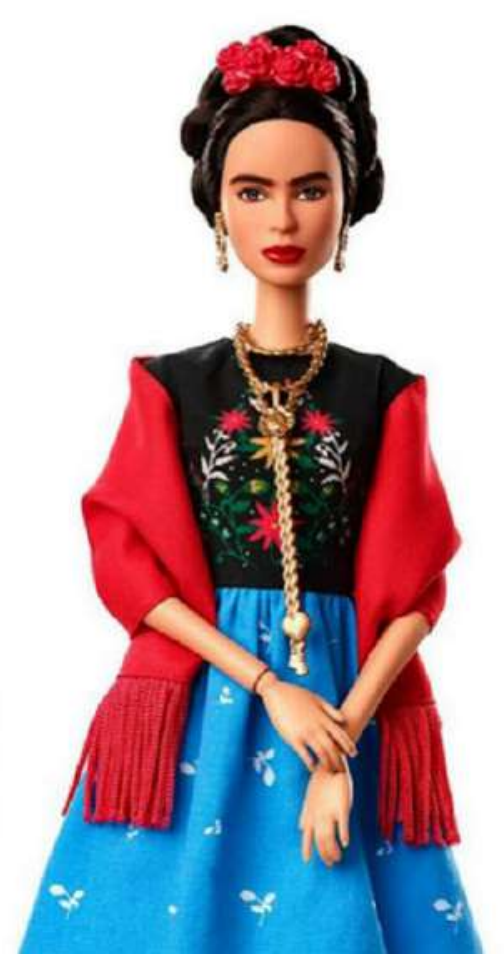

Fuente: CNN Español, "La Barbie de Frida Kahlo no se venderá en México por orden de un juez", 2018.

En su amplia producción de muñecas "pretendidamente multiculturales", Mattel ha impuesto la belleza caucásica de Barbie como modelo a seguir. Así, en todas sus variantes las muñecas se adecuan al mismo patrón fenotípico con una única variante: el color de piel. En el caso de la muñeca "Frida", la muñeca parece rendir homenaje a la imagen de Barbie paradójicamente. En opinión de la directora de teatro Jesusa Rodríguez todo lo que fue, es y será Frida no puede reducirse a su uso comercial, pues ella era "una mujer de carne y hueso, que no es una mercancía, sino una comunista que salía a las calles a manifestarse, y mucho más sexuada que cualquier Barbie".

A partir de lo anterior, es hora de devolverle a la artista "un poco de la dignidad que le ha arrebatado la "fridazación", la cual ha llegado al extremo de reflejar incluso violencia de género al comercializar productos como pañales nocturnos para adultos marca Frida Kahlo" (citada en Mateos-Vega y Flores, 2018). 
Su imagen pública ha sido deformada como también refiere el crítico teatral Bruce Swansey (citado en Mateos-Vega y Flores, 2018). Efectivamente, la imagen de Kahlo ha sido sometida a un uso instrumental, como fenómeno que obedece a la lógica mercantilista de las industrias culturales que, en la posmodernidad, convierten la cultura y el arte en un negocio lucrativo para el entretenimiento de masas.

Figura 2. Barbie-Frida (2018)

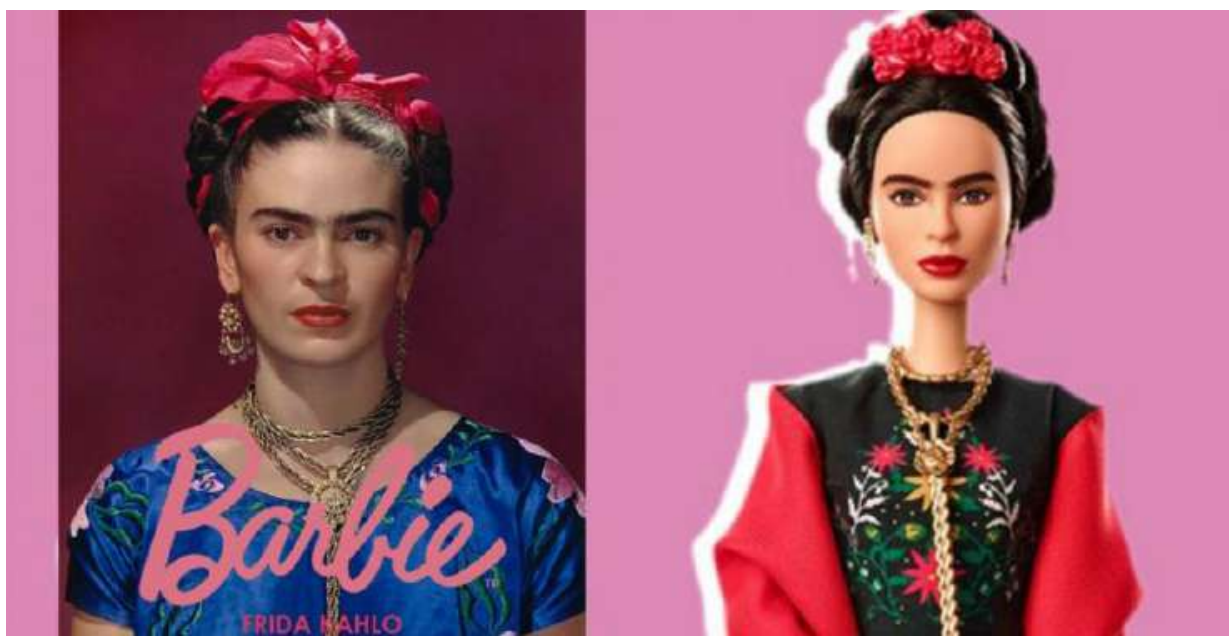

Fuente: La razón Online, "Prohíben vender en México muñecas Barbies como imagen de Frida Kahlo", 2018.

\section{Instrumentalización de la cultura y alienación de género}

Desde la teoría crítica de la Escuela de Frankfurt", el concepto de "industria cultural" implica una política de uso instrumental de la cultura en la que los medios de comunicación masiva producen a las propias industrias culturales al transmitir sus contenidos ideológicos. Esta clara cosificación de la cultura, junto a la consecuente pérdida de sus elementos humanísticos, es la concepción imperante del sentido de la vida en la era posmoderna banalizada.

\footnotetext{
Theodor Adorno planteó en Dialéctica de la llustración (1944-1947), obra escrita conjuntamente con Max Horkheimer, el concepto de "Industria Cultural", para describir la forma en que el capitalismo transforma el arte y la cultura, en mercancías. A partir de la lógica mercantilista la concepción de arte tradicional desaparece para dar paso a su transformación en producto de masas, circunscrito a la dinámica de los modos de producción de mercancías estandarizadas.
} 
Encuentra satisfacción en la trivialización, la funcionalidad y el consumo masivo, acordes con la alienación de la vida cotidiana y pública de la sociedad. De ahí que la novedad, la distracción fácil, la superficialidad, la irracionalidad y la violencia se impongan a las masas toda vez que ellas mismas las demandan en tanto entes enajenados por el sistema: "Las masas tienen lo que desean y se aferran obstinadamente a la ideología mediante la cual se las esclaviza. El funesto apego del pueblo al mal que se le hace" (Horkheimer y Adorno, 2009 [1944-1947], p. 178). En esta tesitura, Adorno y Horkheimer subrayan:

[L]a barbarie estética cumple hoy la amenaza que pesa sobre las creaciones espirituales desde que comenzaron a ser reunidas y neutralizadas como cultura [y aseveran que el] denominador común "cultura" contiene ya virtualmente la toma de posesión, el encasillamiento, la clasificación, que entrega la cultura al reino de la administración. (2009[1944-1947], p. 175-176)

El ámbito en el que se desenvuelve la industria juguetera corresponde al de la cultura de la diversión. Esta forma parte del vasto universo de las denominadas industrias de bienes simbólicos que contribuyen a generar imaginarios que respondan a los intereses de la dictadura cultural de la ideología dominante. En este sentido, la industria juguetera constituye una instancia más de la manipulación y enajenación de la subjetividad de las masas en función del consumismo y el fetichismo de las mercancías.

En tanto producto cultural inmerso en el sistema de producción masiva, Barbie es la mercancía que Mattel, Inc. ha promocionado a través de feroces y omnipresentes campañas de publicidad global para colonizar la subjetividad infantil. Daniel Mato (2007) ha señalado la importancia que tienen los juguetes y los juegos en la producción de sentido, de tal modo que los juguetes producidos industrialmente inducen formas de juego, sugeridas desde el empaque o a través de pautas publicitarias.

De esta forma, el consumo de bienes culturales implica el consumo de significados e interpretaciones. Para conocer el carácter cultural de la industria del juguete se tiene que considerar el empaque, las formas de juego y la publicidad, todo ello en contexto. Esto se advierte en la muñeca Barbie que se presenta como "estereotipo de figura femenina que no solo descalifica a quienes se alejan de él, sino que numerosos especialistas han aducido que promueve la anorexia" (Mato, 2007, p. 139). Además, este juguete es un objeto de consumo para coleccionistas, quienes poseen sentidos particulares, distintos de aquellos que los niños configuran a través del juego, como en el caso de la serie Inspiring Women dirigida a "adultos coleccionistas" y con la que se pretendió emular a Frida Khalo. 
En este sentido, la industria cultural juguetera desempeña el papel de adiestradora de la subjetividad de género que la sociedad patriarcal demanda. Barbie cumple con esta función al moldear la mentalidad de las niñas para que ejerzan su rol de féminas, "hembras" glamurosamente domesticadas, subordinadas a los imperativos del modelo de feminidad ideado por la subjetividad de los representantes de la masculinidad hegemónica que exigen que este ideal se reproduzca.

Ante dicho escenario, el feminismo plantea la toma de conciencia acerca de este malestar de la cultura, de la negatividad que generan las muñecas al replicar los estereotipos que emulan el modelo patriarcal de feminidad a través del juego. Por tanto, el feminismo ha recalcado la necesidad de desalentar los juegos que reproduzcan enajenación de género, al tiempo que se fomente el uso de juguetes que desarrollen la creatividad de niñas y niños por igual sin diferenciación genérica.

\section{Barbie: icono de la cultura pop}

En su papel de reproductoras de la ideología hegemónica, las industrias culturales se sirven de las Tecnologías de la Información y la Comunicación (TIC) para crear (a través de la publicidad) las imágenes icónicas de la sociedad de masas. Tal es el caso de Barbie y Frida, cuyas imágenes han sido reproducidas hasta la saciedad en el contexto de la globalización cultural, razón por la cual las dos (2) figuras circulan como iconos de la cultura pop (Barragán, 2017).

La constitución de Barbie en icono cultural se origina en el momento mismo en que es consagrada como símbolo de la cultura popular norteamericana, del american way of lifey del arte pop. Su transformación en insumo simbólico ocurre durante un momento clave de la historia norteamericana en 1976, cuando en la celebración del bicentenario de la independencia de los Estados Unidos se depositó una Barbie y otros objetos característicos de la cultura estadounidense dentro de una cápsula del tiempo que será abierta en 2076. Al respecto, Riddick (2001) observa que con este acto se le concedió a la muñeca un lugar permanente en la historia de los Estados Unidos como icono de América.

Sin duda, estos hechos la consagraron simbólicamente como un icono representativo de la identidad e historia norteamericana. Ahora, Barbie se encuentra presente en la cultura visual contemporánea. Ruth Handler, quien concibió la idea de este juguete, se enorgullecía cuando afirmaba que: "Barbie es una institución, registrada ante derechos de autor, como una obra de arte" (citada en Weissman, 1999, p. 12). Tenía razón. Con el tiempo la muñeca se convirtió en el icono del 
Pop Art, así como la musa de muchos de los artistas posmodernos que deconstruyen su imagen por medio del pastiche, la parodia, el humor negro o la pornografía.

Artistas como Andy Warhol, Roy Lichtenstein, Robert Rauschenberg, David Hockney, Jasper Jones, por citar algunos, se inspiraron en los objetos representativos del american way of life para realizar sus obras. Transformaron los iconos populares en artísticos, dispuestos para el consumo de masas mediante infinidad de reproducciones difundidas por los medios de comunicación masiva. Sus discursos visuales expresan los imperativos tecnológicos de su época, el contexto de los años 1960 en el que se desenvuelve la cultura del desecho.

Así, por ejemplo, se incluyen los artículos de la producción masiva, la banalización de la vida cotidiana de la sociedad, la exaltación de sus ídolos de cine, de sus marcas favoritas o de sus productos de consumo que van desde los cómics hasta los símbolos nacionales en su carácter popular. Son célebres las obras de Warhol como la Lata de sopa Campbell's, las Botellas de Coca-Cola, los Billetes de dólar, la figura de Mickey Mouse, los rostros de Marilyn Monroe, Elizabeth Taylor o Michael Jackson. Sus imágenes fueron inmortalizadas en cuadros de gran formato mediante la utilización de vibrantes colores planos. Warhol declaró en una ocasión: "Me encanta L.A., me encanta Hollywood, todo el mundo es plástico, pero me encanta el plástico, quiero ser plástico" (citado en Moore, 2015).

Fue Andy Warhol el primer creador que consagró a Barbie como icono artístico de la cultura pop cuando en 1985 pintó a Billy Boy² como Barbie, el retrato muestra a la muñeca con su rubia cabellera y brillantes ojos azules contra un fondo de color azul. En una segunda versión que el artista realizó por encargo de Mattel en 1986, Barbie aparece sobre fondo naranja-rojo. La obra es exhibida en la compañía.

2 Inspirado en un joven diseñador de joyas de 23 años llamado Billy Boy*, en 1985 Andy Warhol realizó la obra Barbie, Retrato de Billy Boy*.Esto significa que la pintura representa al diseñador como Barbie. El retrato muestra a la muñeca con su rubia cabellera y los ojos azules brillantes, contra un fondo de color azul del polvo que el creador bautizó como "Billy Boy azul". Billy Boy* escribía su nombre con un asterisco. 
Figura 3. Andy Warhol, Barbie (1985)

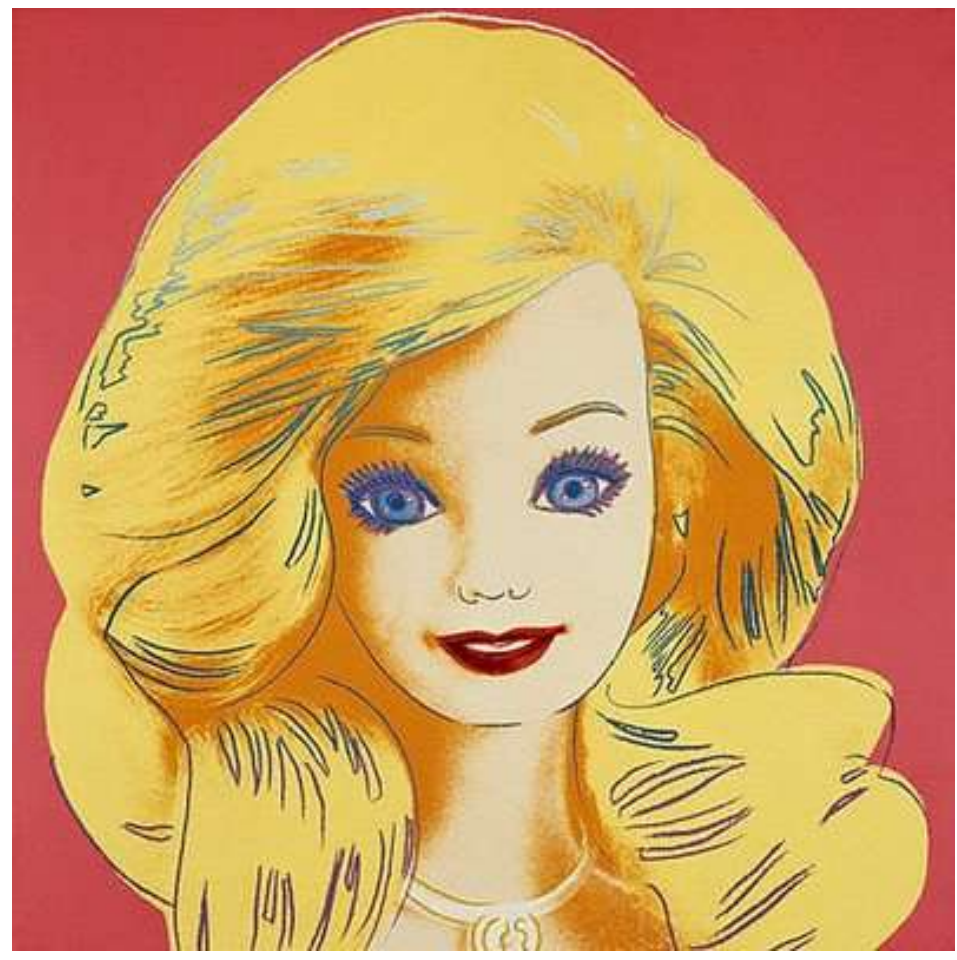

Fuente: Moore, "Por qué Warhol pintó a Barbie”, 2015.

Cabe recordar que varias fueron las marcas consagradas por los artistas pop. En una entrevista, Andy Warhol se pronunció a favor de la reproducción técnica vanagloriándose de ser un denunciador de la farsa del gran arte y glorificador de la reproducción serial. Efectivamente el Pop Art tenía un sentido desmitificador, al tiempo que mistificaba la objetualización de la cultura con la consecuente alienación consumista.

A este respecto, Giles Lipovetsky y Serroy (2015) postulan que la estetización de la era modernaimplicalacoexistenciadeunsistemadicotómicoqueoponelaproducción delujo dealtovalor creativo ala producción industrial en seriesin estilo, ni originalidad, destinadas a las masas. Ello involucra un sistema divergente que contrapone estilo e industria, artey producción en masa, vanguardiay pacotilla kitsch. En esta dinámica las industrias culturales han sido los vehículos que han facilitado las transformaciones de la gran distribución: 
Es forzoso reconocer que son más las lógicas de estetización en masa que la esfera del arte propiamente dicha. Con el advenimiento de las artes de masas y de las estéticas comerciales que se ejemplifican en el cine, la fotografía, la publicidad, la música grabada, el diseño, los grandes almacenes, la moda, los cosméticos, se desencadena por primera vez una dinámica de producción y de consumo estético a escala mayoritaria. [...] con la sociedad de consumo de masas se impuso una cultura estética de masas, tanto a través de los nuevos valores celebrados [hedonismo, entretenimiento, diversión, moda...] como a través de la proliferación de bienes materiales y simbólicos, cargados de valor formal y emocional. En realidad, el universo industrial y comercial ha sido el principal artesano de la estilización del mundo moderno y de una expansión democrática. (Lipovetsky y Serroy, 2015, pp. 19-20)

En suma, en la denominada "era transestética": "Después del arte para los Dioses, el arte para los príncipesy el arte por el arte, lo que triunfa ahora es el arte para el mercado" (Lipovetsky y Serroy, 2015, p. 21). Warhol es quizás la figura paradigmática que fusiona el artey el comercio. Lipovetsky y Serroy describen esta relación en los siguientes términos:

Estamos en el momento en que los cruzamientos del capitalismo y el arte se corresponden a lo grande con el proyecto de Warhol de fusionar el arte y el universo comercial. El capitalismo ha realizado una revolución parecida a la de Warhol en el concepto de arte que él impulsó. Mientras se produce el mestizaje de producción industrial y arte, el arte quiere ser negocio, de acuerdo con la célebre fórmula de Warhol: "Ser bueno en los negocios es la forma de arte más fascinante. Ganar dinero es arte, trabajar es arte y un buen negocio es el mejor arte". (p. 74)

Asimismo, Lipovetsky y Serroy (2015) destacan que, en el capitalismo artístico, el papel que juegan los emporios transnacionales resulta vital en beneficio de los intereses que desarrollan las industrias culturales. De tal modo que el universo del arte, de lo bello y de la cultura se ven reestructurados por las leyes de lo híper en la dinámica de los flujos financieros globales, representados por las multinacionales, la escalada financiera, la hipertrofia promocional y comercial. Lo que antes era una esfera marginal y periférica se ha convertido en una realidad de dimensión planetaria que comporta inversiones e intereses financieros descomunales. 
Mattel en 2015, en conjunción con la Fundación Andy Warhol, lanzó la Barbie Andy Warhol, una muñeca de colección para celebrar a estas dos figuras de la cultura pop: "Nuestra alianza con la Fundación Andy Warhol celebra a estas dos icónicas marcas de prestigio en la cultura pop" señaló Evelyn Mazzocco, gerente general de Barbie (citada en Notimex, 2015). Por su parte, Michael Dayton Hermann, de la Fundación Andy Warhol, expresó que: "Es la reunión de dos íconos atemporales de la cultura pop, para celebrar la individualidad" (citado en Notimex, 2015).

Este fenómeno cultural obedece a lo que Adorno plantea como el proceso mediante el cual el arte ha sido subordinado y circunscrito al autodenominado sistema de las industrias culturales. De tal manera que una obra ya no es concebida en su dimensión espiritual, con aura, sino debido a una marca. En este sentido, cabe mencionar la consideración de Carlos Fajardo, quien enuncia como característica de la estetización posmoderna al hecho de transformar un objeto de la vida cotidiana en fetiche del arte:

Cierto es que esta "estetización" contiene una decadencia de aura y una escasez de magia, ilusión y ensoñación por su afán decorativo efímero. El ornamento y su falsa catarsis estética transforman lo real en un objeto fetiche de valor de cambio más que de uso. Por lo mismo, la "estetización" se está realizando en todas partes, desde lo altamente elaborado hasta la banalización del gusto y del juicio. Toda la cultura está pasando de los medios al público como estética realizada, como fenómeno de moda y publicidad, constituyéndose en una de las utopías de la masificación. (Fajardo, 2001, p. 99)

Al ser concebida como "obra de arte", Barbie posee "aura". Carreón Blaine (2013) señala acertadamente que, a diferencia de las reproducciones mecanizadas de una obra, la muñeca no constituye una mera reproducción. No en el sentido de la fotografía impresa de un negativo del que es posible obtener gran cantidad de "originales", sino que cada Barbie puede ser considerada como una "obra de arte", ya que cada muñeca contiene el "aura" del original y está al alcance de todos. Esta lógica puede explicar el procedimiento que Mattel ha seguido para posicionar a su marca Barbie en el mercado de bienes simbólicos hasta ponerla en circulación a través de museos, galerías o subastas de arte.

\section{Consagración artística de Barbie}

La consagración de Barbie como insumo simbólico involucra un fenómeno artístico que, desde la perspectiva de la sociología del arte, conlleva su legitimación dentro del campo del arte. De acuerdo con el sociólogo Pierre Bourdieu (1990, pp. 135-141), el 
campo social es concebido como un espacio de juego construido históricamente en el que concurren distintos actores y agentes asociados con diversos intereses inherentes al campo mismo.

A partir de sus propias instituciones y leyes de funcionamiento, se rigen por normas válidas para todos. Sus relaciones están definidas por la posesión o producción de una forma específica de capital concomitante, denominado como capital simbólico. Entre las interacciones que realizan los diversos agentes se encuentran actividades como la producción de obras de arte, la gestión cultural, la crítica de arte, la curaduría, las visitas a museos, las conferencias acerca del arte, la realización de ferias y bienales artísticas, las subastas, entre otros con el objetivo de producir el capital que se provee. Tanto por sus posiciones dentro del campo, como por sus habitus ${ }^{3}$, los agentes habrán de poner en juego estrategias que los definirán como generadores de valor simbólico, toda vez que se adjudican la autoridad para legitimar las visiones, ideologías, discursos o paradigmas. Por tanto:

La valoración de la obra de arte constituye una praxis simbólica e ideológica de los agentes del campo del arte: artistas, galeristas, curadores, coleccionistas, críticos, historiadores y funcionarios culturales, quienes determinan de acuerdo con sus muy particulares ideologías estéticas qué es arte y qué no lo es. Mediante consensos y disensos, idean, conceptualizan y proporcionan la definición de lo que debe entenderse por valores artísticos intrínsecos a la obra, ya sea en su dimensión formal, sensible, conceptual, simbólica, ideológica, cultural o social. Con potestad simbólica atribuyen valores artísticos a determinadas obras, legitimando la exposición de las mismas en los espacios institucionales del arte (museos, galerías, bienales, ferias, etcétera) y su circulación en el mercado del arte. De esta manera, dotan de capital simbólico a la obra artística, esto es, de los valores que la consagran y que se traducen en índices de su tasación en el mercado del arte. (Barbosa, 2016, p. 2)

3 Los habitus se conceptualizan como productos de condicionamientos asociados a una forma particular de existencia. Aun cuando poseen un carácter arbitrario, se presentan para los sujetos no solo como necesarios, sino hasta naturales. Producto de la historia, los habitus producen prácticas individuales y colectivas. Conforme a los principios (schèmes) engendrados por la historia, aseguran la presencia activa de las experiencias pasadas que depositan en cada organismo bajo la forma de principios de percepción, pensamiento y acción. Asimismo, aseguran con mayor precisión que las reglas formales y normas explícitas consecuente sus prácticas a través del tiempo (Bourdieu, 1991, pp. 94-95). 
La praxis de valoración de la obra de arte se finca en la aceptación de su valor cultural. De ahí que: "La obra de arte es un objeto que solo existe como tal por la creencia (colectiva) que lo conoce y lo reconoce obra de arte" (Bourdieu citado en Barbosa, 2016, p. 2). Marc Spiegler, director global de Art Basel y sus tres (3) sedes (Basilea, Miami y Hong Kong) además de ser un actor clave en el mercado del arte, proporciona una idea de la forma en que opera la consagración de los bienes culturales y su canonización institucional. Lo que se traduce en valor simbólico en el consecuente valor comercial adquirido una vez dentro del mercado del arte:

Cuando hablamos de gran arte no importa si nos referimos al diseño, a la moda o a lo que sea [...] Los coleccionistas y los galeristas pueden moldear el mercado, hablando de los jóvenes artistas, más fácilmente que las instituciones por la manera en que estas últimas trabajan. Pero por otra parte, un artista que ha sido aceptado por los curadores, que ha tenido la oportunidad de tener exposiciones en museos, tiene un mercado mucho más estable que un artista que es puramente un producto de coleccionistas. Una subasta organizada por un coleccionista puede hacer hot a un artista, pero eso no lo convierte en un artista. Muy pocos coleccionistas están a nivel de un museo público. Solo un museo puede canonizar a un artista. Esa es la razón por la cual los galeristas más inteligentes venden con descuentos a museos públicos y privados. (citado en Lammers, 2016)

A través de esta dinámica los agentes realizan los actos primordiales que definen y atribuyen valores artísticos, al tiempo que instituyen la creencia colectiva en los valores conferidos. De esta forma ejercen el poder de consagrar simbólicamente la obra artística (Barbosa, 2016, p. 2). Asimismo, el poder de consagración que detentan los artistas se patentiza cuando legitiman la incursión de Barbie dentro del campo de las artes visuales. Esto es, cuando la elevan a icono del arte y adquiere un valor simbólico.

Una vez internada en el circuito institucional de las artes, opera la praxis de su valoración. Luego encuentra un nicho de comercialización en el mercado. Los artistas contribuyen a legitimar al fetiche, al elegirlo como objeto de sus obras, ya sea con una perspectiva artística, crítica o mediante los discursos visuales que la deconstruyen. En suma, su exaltación mercantil se reafirma. 


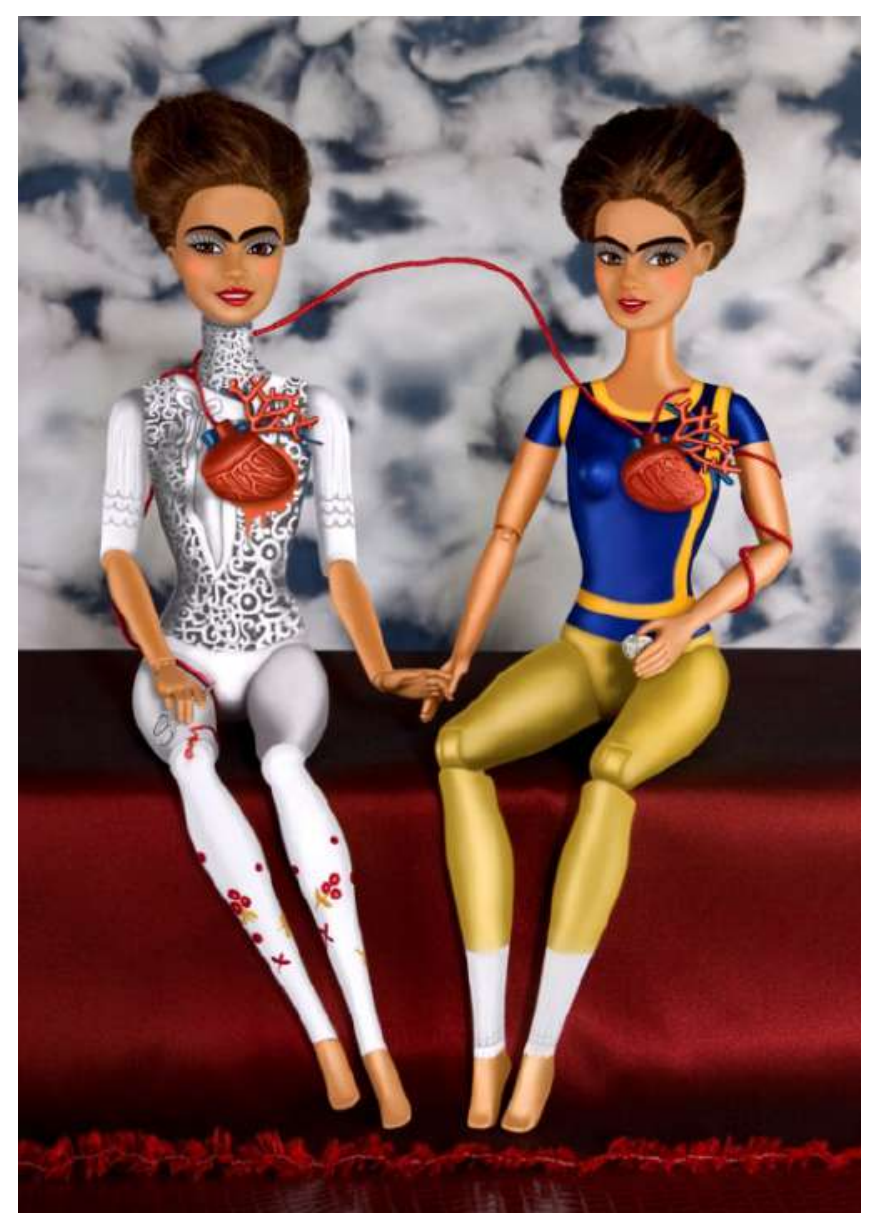

Fuente:Théry, "Echange à Coeur ouvert. Clin D'oeil à Frida Kahlo", 2015.

En este contexto, varios han sido los $\operatorname{artistas}^{4}$ que se han encargado de construir toda una iconografía "barbiana", en la que el fetiche de la cultura pop es representado posando como protagonista de las obras maestras de la pintura occidental; o como terrorista suicida, desnuda dentro de una copa de Martini. Ya sea representando la antítesis de su modelo original o emulándolo.

\footnotetext{
4 Se pueden citar los nombres de Catherine Théry, Jocelyne Grivaud, Tom Forsynthe, Simon Tyszko, Mariel Clayton, Sarah Haney, Dina Goldstein, Karin Schwarz, Olivier Rebufa, Carmela García o Carlos Morán, entre otros.
} 
Figura 5. Le Bain (1990)

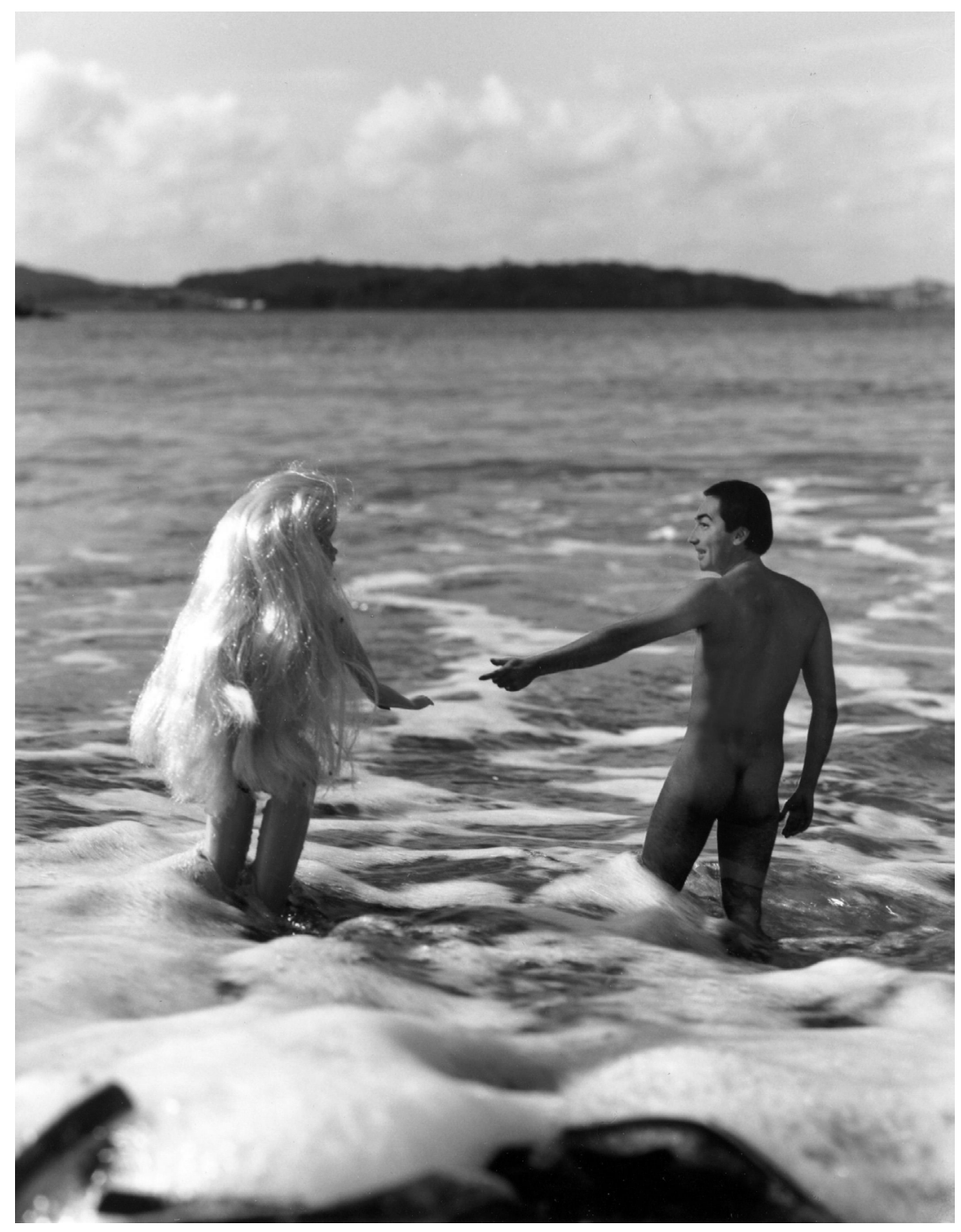

Fuente: Olivier Rebufa, "Le Bain”, 1990. 
Figura 6. Icon Inside No. 1

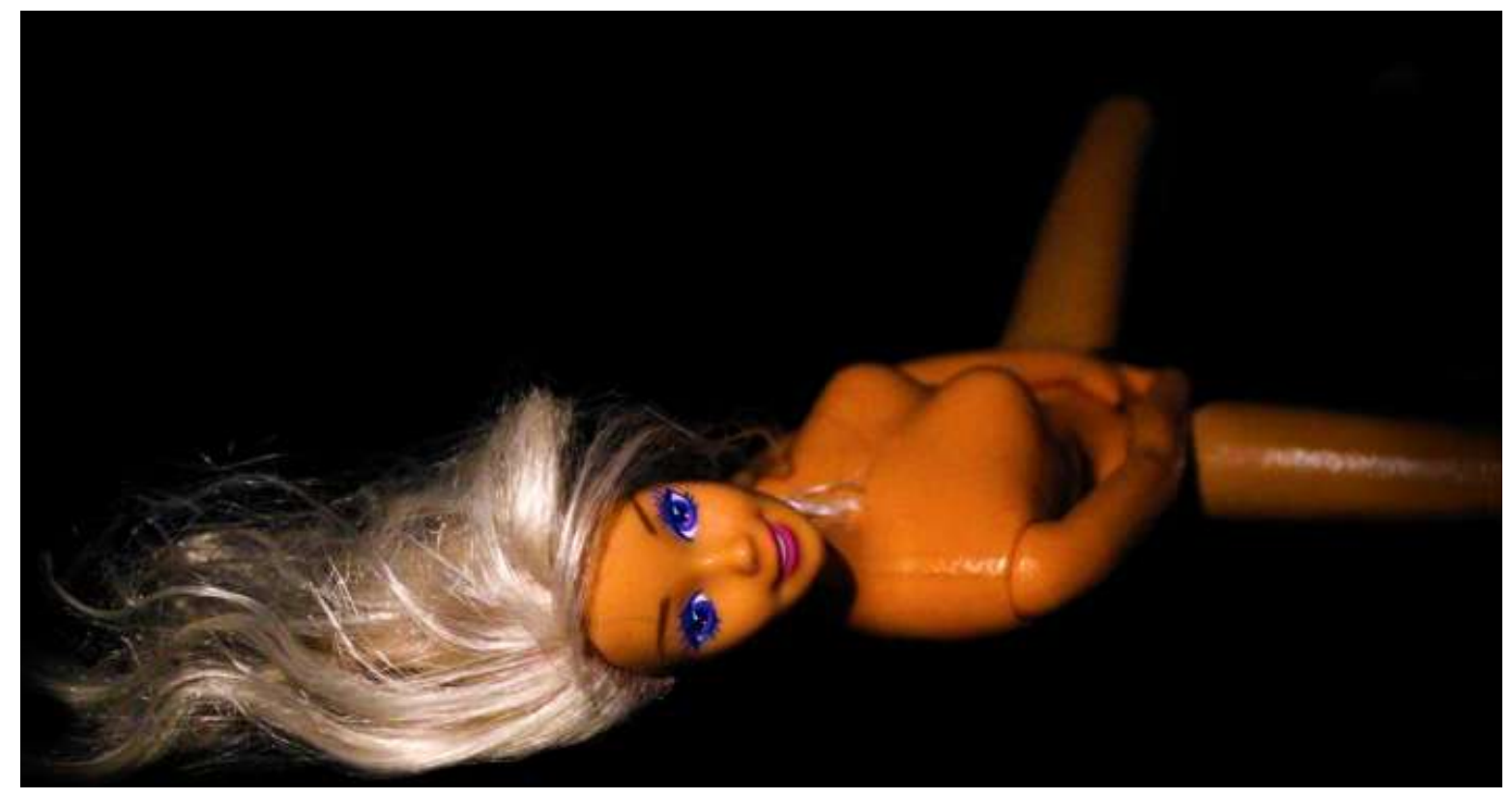

Fuente: Carlos Morán, "Icon Inside No. 1", 2013. 


\section{1}

Figura 7. Bárbaras garotas 31

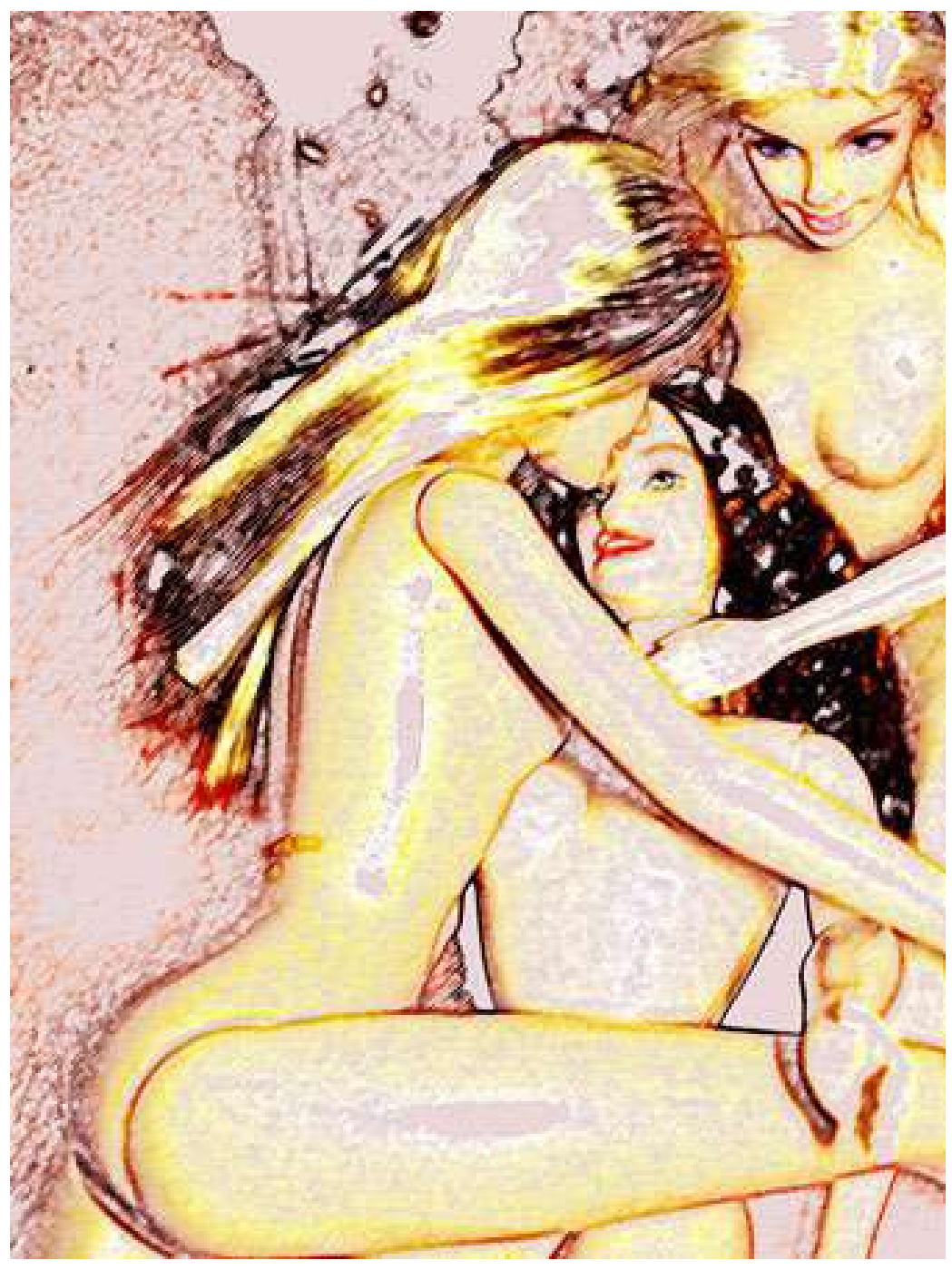

Fuente: Karin Schwarz, "Bárbaras garotas 31", 2005. 
Figura 8. Heatwave Barbie

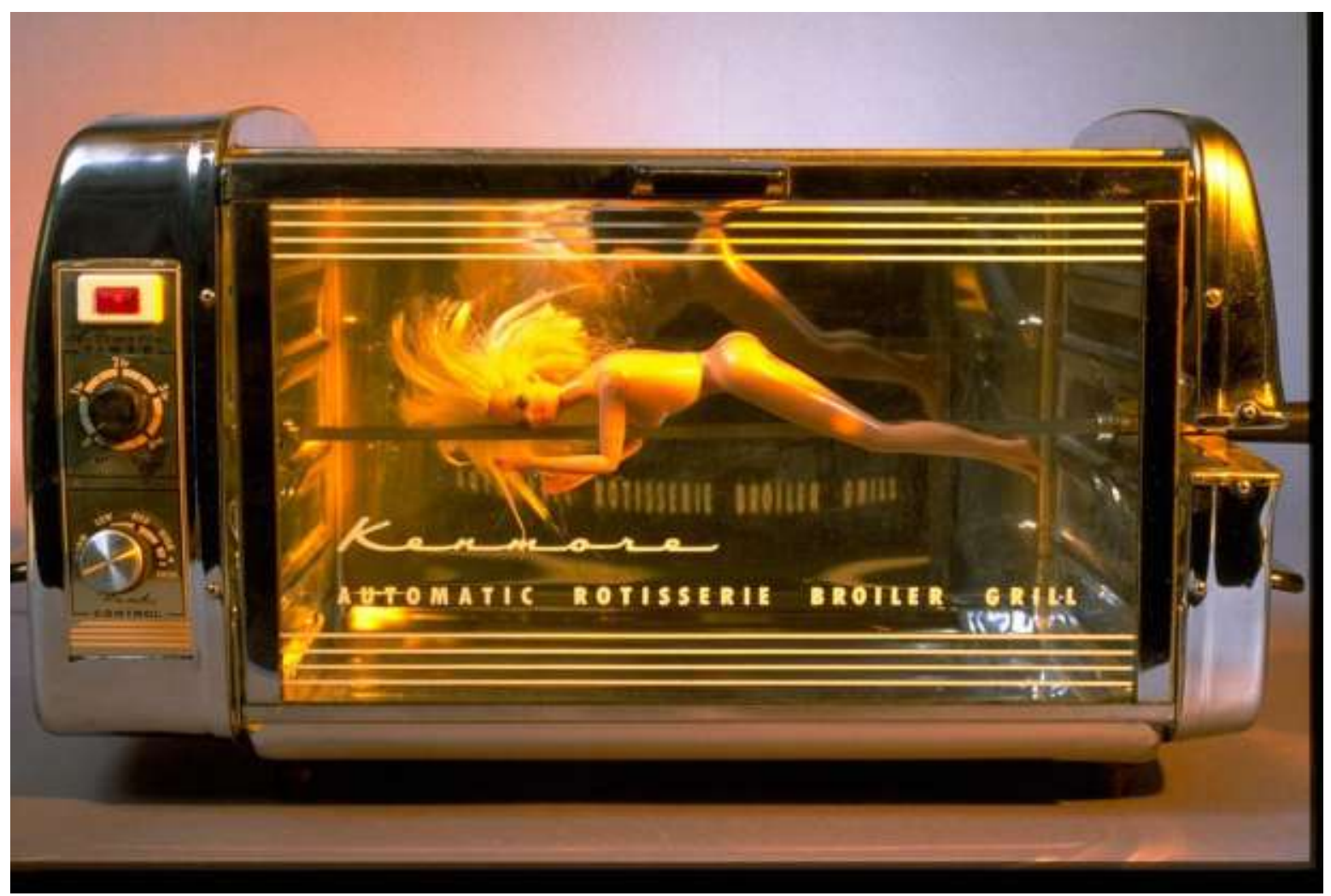

Fuente: Tom Forsythe, "Heatwave Barbie", 1998. 
Figura 9. HQ-dynamic-barbie

\section{3}

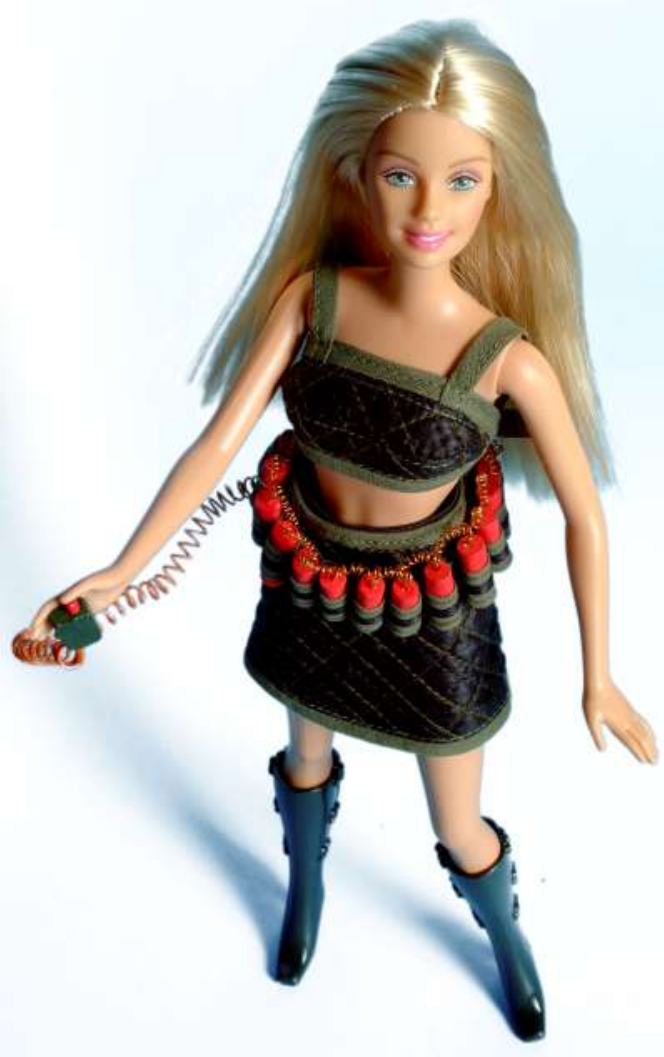

Fuente: Tyszko, "HQ-dynamic-barbie", 2002.

Por su parte, Mattel, Inc. ha desplegado una estrategia global para posicionar a su juguete dentro de prestigiados museos 5 , a través de exposiciones de Barbie, en calidad de objeto artístico, con lo cual logra traspasar su ámbito en la industria cultural juguetera y penetrar en la industria cultural artística. Así, posicionando a su marca como producto de consumo estético en el campo del arte, donde circula en museos, galerías y subastas.

5 Algunos de ellos son el Cornell Museum de Delray Beach, Florida; el Museo de las Artes Decorativas del palacio de Louvre, París; el Complejo del Vittoriano de Roma; Museo de Arte Moderno de Bogotá (Mambo); y el Museo Franz Mayer, México. 


\section{4}

\section{Frida: de icono feminista a Barbie}

"Pies para qué los quiero, si tengo alas pá volar"

Frida Kahlo

Sin duda, la fama de la artista Frida Kahlo (así como su obra) han trascendido a nivel mundial. Su imagen y sus obras han sido replicadas en cientos de artículos de producción masiva:

Su imagen con sus características flores y su gruesa ceja y bigote puede encontrarse en un sinfín de espacios como películas de Disney ("Coco"), canciones y hasta Barbies, eso sin dejar de lado productos como ropa, tazas, mochilas, aretes, cuadernos, etc. (Martínez, 2020)

Tal comercialización ha corrido a cargo de las industrias culturales que la convirtieron en un fenómeno de masas, descontextualizando el verdadero significado histórico y simbólico del que surgieron. Primeramente, habrá que recordar que la figura de Frida Kahlo se constituyó en símbolo de movimientos sociales como el feminismo, las personas con capacidades diferentes, de la lucha LGBT que involucra el reconocimiento de los derechos humanos, civiles, sociales, políticos y sexuales de "lesbianas", "gais", "bisexuales", "transgénero" y "transexuales".

También es retomada como icono de la mexicanidad por las feministas estadounidenses de ascendencia mexicana, las "chicanas" que, en las décadas de los 1960 y 1970, reviven sus raíces identitarias. La "Fridomanía", es decir, el culto que se rinde a todo lo que tiene que ver con Frida, originó que se le posicionara a nivel de grandes pintores como Van Gogh, Picasso, Dalí o Andy Warhol.

La vida y obra de la artista ejemplificaban la lucha de una mujer que se sobrepuso a las limitaciones físicas ocasionadas por un accidente que la dejó postrada en cama durante largos periodos. Frida se atrevió a ser ella misma y plasmar los detalles más íntimos de su vida a través de diferentes temáticas plásticas como sus abortos, el amor que sentía por Diego Rivera, el erotismo, la enfermedad o la violencia de género que retomaba de las notas periodísticas de los años treinta.

Para este efecto se pueden citar las obras de Unos cuantos piquetitos (1935), El accidente (1925), La operación cesárea (1932), Las dos Fridas (1939), Diego y yo (1949), La columna rota (1944), El ciervo herido (1940). En opinión de Araceli Rico (1992) "sus imágenes traducen los estados de ánimo de su creadora, reflejando su intimidad y manteniendo una estrecha relación entre vida interior y exterior". (p. 29, 47) 
De tal forma, para Frida las relaciones que existen entre la creación en el arte y la vida (o más bien entre la pintura y la experiencia corporal) son términos complementarios, intercambiables el uno por el otro. Su creatividad le permitió construirse una identidad transgresora que, en muchos sentidos, subvertía los imperativos de género de la mayoría de las mujeres de su época. Sus convicciones políticas y sociales la llevaron a participar en la vida pública del país a través de su militancia en el Partido Comunista Mexicano, a salir a las calles y manifestarse.

Como todo personaje de la vida real que ha sido transformado en mito, su verdadera dimensión histórica se ha tergiversado. Así, se le ha querido identificar como una mujer dependiente de Diego Rivera, tanto en lo emocional como en lo económico, lo cual descontextualiza sus verdaderas circunstancias en el ámbito público y privado. Su personalidad resulta indisociable de sus pulsiones afectivas, mientras que su figura artística y su obra, devienen concomitantes de sus capacidades intelectuales y creativas. Precisamente su compleja personalidad es lo que le permitió construir una imagen identitaria opuesta a los imperativos estéticos y genéricos de su momento histórico. Mientras que sus talentos artísticos la llevaron a incursionar en el mundo del arte dominado por los varones.

Su identidad artística corresponde al ámbito de la vida pública, mientras que su identidad privada se circunscribe a su vida íntima, sexual y amorosa, a la idolatría que sentía por Diego: "El amor vehemente a Diego Rivera expresado directa y conmovedoramente por su pintura" (Rico, 1992, p. 153); expresión de sentimientos que de ninguna manera le resta carácter, como lo manifestó a lo largo de su trayectoria. Segura de sí misma, Frida se forjó una identidad femenina fuerte, al tiempo que se empoderó a través de su actividad artística y de la intensa vida social que mantuvo con los personajes masculinos y femeninos notables de su tiempo, intelectuales, artistas y políticos.

En su identidad de género, fue revolucionaria, ya que rompió con los estereotipos que la sociedad patriarcal de la época demandaba a las mujeres. De esta forma, trastocó su identidad al vestirse con ropas masculinas como en el Autorretrato con pelo corto (1940), donde aparece sentada en una silla, vestida con camisa y traje de hombre de colores oscuros, el traje es de una talla mayor.

Asimismo, porta unas tijeras en la mano derecha con las que se ha cortado su cabellera de gruesas trenzas, cuyos restos todavía sostiene en la mano izquierda. En el piso, esparcidos por todas partes hay largos cabellos. El único atisbo de feminidad que destaca son los aretes que lleva puestos. Esta obra la realizó después de su divorcio con Diego Rivera en 1939, por lo cual se puede inferir que connota un acto simbólico de dolor, en el que se desprende de los rasgos "femeninos" que la distinguían en su 
matrimonio con el pintor — como su acentuada feminidad, caracterizada por el uso de los trajes mexicanos de tehuana, así como su largo pelo, que tanto gustaba a Diego-.

Con ironía inscribió en la parte superior del cuadro las notas musicales de una canción popular que dice: "Mira qué si te quise, fue por el pelo. Ahora que estás pelona, ya no te quiero". Se ha querido interpretar esta obra como una alegoría del sufrimiento causado por la infidelidad de Diego Rivera con la hermana de la artista, Cristina. Al respecto, Ramírez Peña (2016) opina que es una:

[A]cción asumida con un sentir masculino mientras que con tijeras corta el tan elogiado, cabello largo y oscuro, además de renunciar a las blusas y faldas típicas las cuales pasaban a ser algunos de los motivos que la hacían ganarse el amor de su esposo, a quien tanto admiraba. (p. 172)

Connotaría, más bien, una renuncia simbólica de su feminidad, socavada por la traición de Diego.

Figura 10. Autorretrato con pelo corto

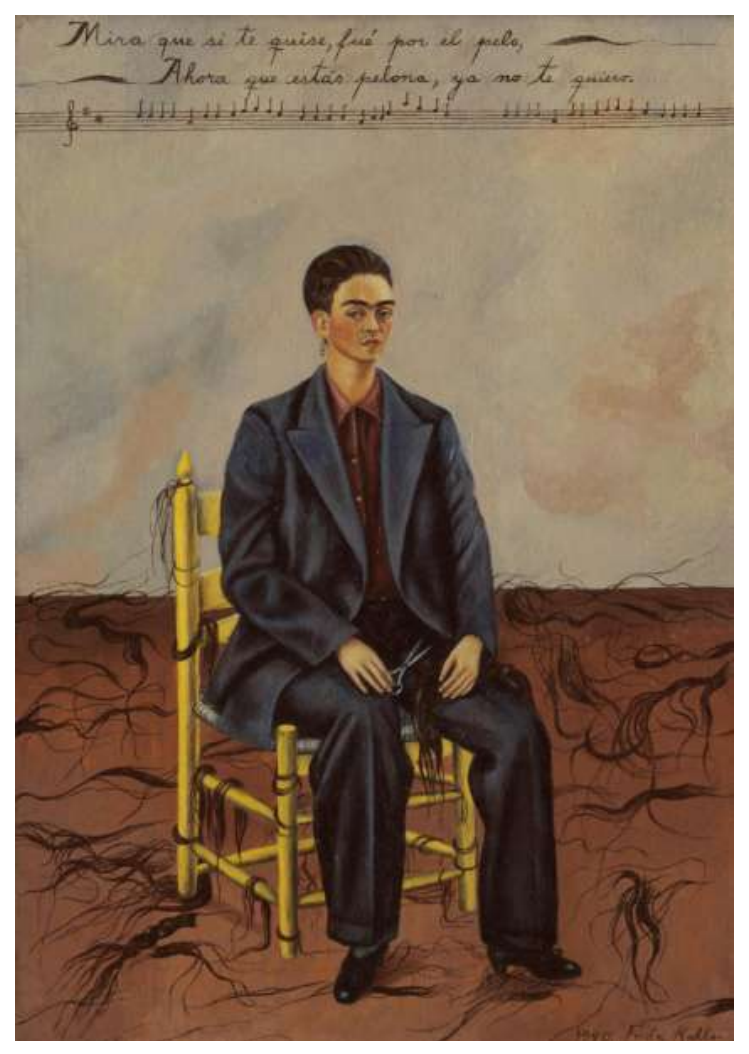

Fuente: Frida Kahlo, "Autorretrato con pelo corto", 1940

(MOMA, Nueva York). 
Una de las obras de Frida que resulta pionera en el arte de mujeres en México, por su temática de denuncia de la violencia de género hacia las mujeres, es Unos cuantos piquetitos (1935). Se trata de una pintura de carácter mórbido basada en un hecho de la vida real. La escena se desarrolla en una habitación en la que solo hay una cama en la que yace una mujer asesinada, víctima de múltiples puñaladas en todo el cuerpo.

En primer plano, aparece la imagen de una mujer desnuda y ensangrentada sobre la cama con la pierna derecha torcida hacia un lado, que porta no más que una media arrugada por debajo de la rodilla; la liga de pulsera que la sujetaba con el adorno de una flor, ahora se ubica en su tobillo; solo calza una zapatilla de color negro. En segundo plano, la figura de un hombre de pie que viste pantalón negro, camisa blanca, pañuelo al cuello y sombrero negro; sostiene un cuchillo en la mano derecha y un pañuelo blanco en la izquierda, con el cual ha limpiado su arma; su vestimenta se aprecia manchada de sangre.

El hombre observa con gesto cínico, en actitud desafiante, el cuerpo inerte de su víctima. Todo el cuadro está impregnado de la sangre, incluso el marco de la obra. En la parte superior del cuadro una paloma blanca y una golondrina sostienen con el pico una cinta con las palabras "iunos cuantos piquetitos!".

Figura 11. Unos cuantos piquetitos

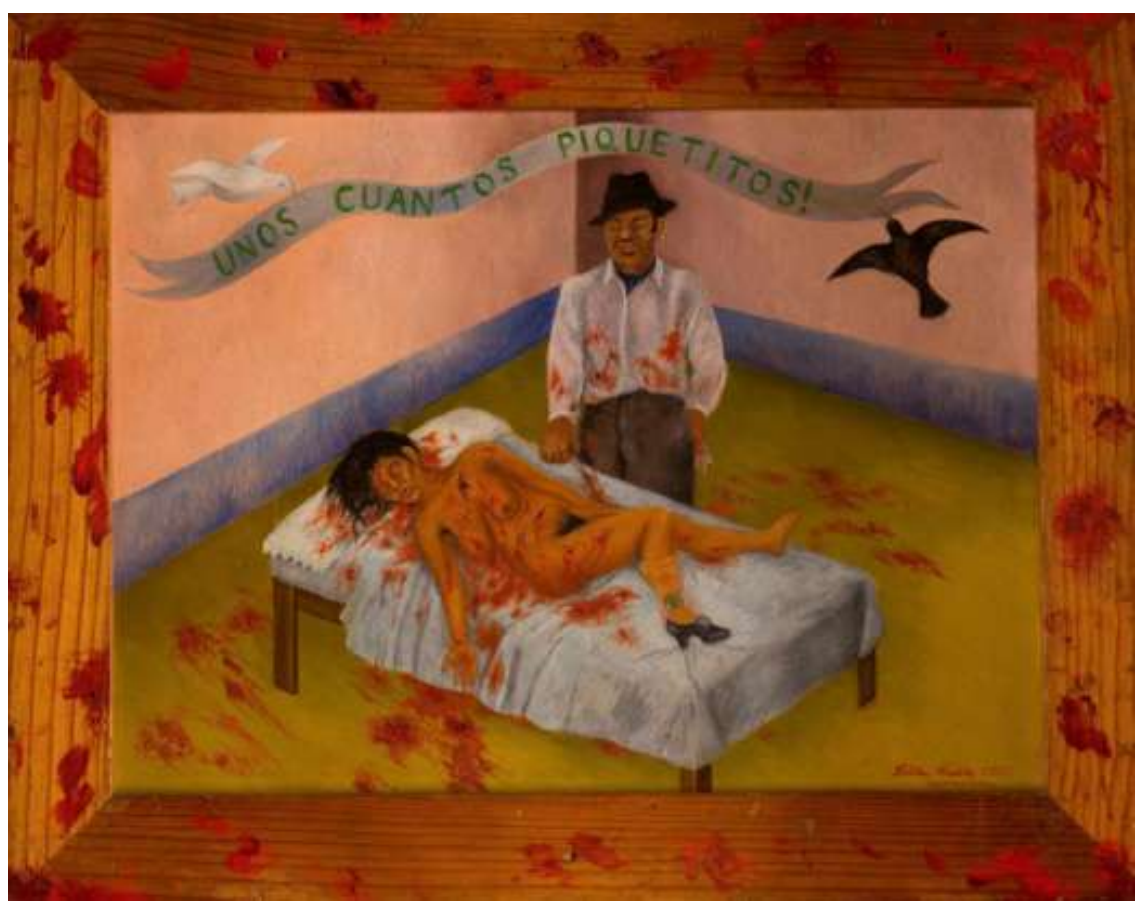

Fuente: Frida Kahlo, "Unos cuantos piquetitos", 1935 (Museo Dolores Olmedo, Ciudad de México). 
Tomada de una noticia periodística de la época, Frida Kahlo recreó este terrible feminicidio que relata cómo un hombre asesinó a su novia de 20 puñaladas. Al comparecer ante el juez el victimario esgrimió "iPero si sólo le di unos cuantos piquetitos!" Frase que da título al cuadro y que denota el sentido irónico del argumento, mismo que en el relato visual de Frida Kahlo expresa, con humor negro, la idiosincrasia del macho mexicano. De hecho, Frida Kahlo le comentó a un amigo que pintó el cuadro "porque en México el asesinato es bastante satisfactorio y natural". Agregó que sintió la necesidad de recrear la escena del crimen porque sentía empatía con la mujer asesinada, ya que ella misma casi había sido "asesinada por la vida". (Herrera, 2004, pp. 234-235)

En el plano económico, Frida Kahlo contempló la posibilidad de vivir de su obra. Hayden Herrera refiere que la primera venta importante que Frida realizó en el verano de 1938, consistió en cuatro (4) cuadros que adquirió la estrella de cine Edward G. Robinson por la cantidad de 200 dólares cada uno. Lo que dio a la artista la idea de vivir de su arte e independizarse económicamente de Diego: "Quedé tan asombrada y maravillada que pensé: 'Así podré ser libre. Podré viajar y hacer lo que quiera sin tener que pedirle dinero a Diego'". (Herrera, 2004, pp. 289-290)

El arte de Frida se impuso en el gusto de la gente que la conocía, tanto así que en abril del mismo año el ensayista y poeta surrealista André Breton vio el trabajo de Frida y quedó impresionado, al grado de ofrecer una exposición de su obra plástica en París. Expresó que el arte de Frida era como "una cinta alrededor de una bomba" (Breton, 1997, p. 143). En 1938, Frida también participó en una exposición colectiva en una Galería de Arte de la Universidad en la Ciudad de México.

El mismo año (1938), ya en el extranjero Frida Kahlo expuso su obra por iniciativa de Julien Levy, quien organizó una exposición en Nueva York, en una galería de arte orientada hacia el surrealismo, ubicada en la calle 51 en Manhattan. A partir de ahí, participó en las exposiciones Mexique en la Galería Renou et Colle de París (1939); en 1940, en Veinte siglos de arte mexicano (1940), Retratos del sig/o XX (1942), ambas en el Museo de Arte Moderno de Nueva York. En 1941 el Instituto de Arte Contemporáneo de Boston la incluyó en la muestra Pintores modernos mexicanos. Asimismo, en 1943 el Museo de Arte de Filadelfia, en Arte mexicano de hoy.

En México, Frida participó en la Exposición Internacional de Surrealismo, (1940); en Cuarenta y cinco autorretratos de pintores mexicanos: Siglos XVIII al XX (1947) en el Palacio de Bellas; en 1949, en la Exposición inaugural del Salón de la Plás- 
tica Mexicana. Finalmente, en 1953 se realizó la única exposición individual de la artista en vida, en la Galería de Arte Contemporáneo de Lola Álvarez Bravo.

Fridase creó una imagen suigéneris quecobró relevanciaartísticaypolíticaatravés del tiempo. De ahí que con la emergencia del feminismo de 1970 en los círculos europeos, su figura haya cobradogran interésparalas mujeres afines al movimiento quela proclamaron como un símbolo de sus vindicaciones. Este boom propició la denominada "fridomanía".

Su recuperación como icono de la lucha de género se debe a sus logros en el ámbito de la plástica, al poder que manifestó reinventándose a través de la auto representación de su subjetividad, de sus experiencias de vida. Con ello logró trascender como imagen pública y colocarse en el imaginario artístico y colectivo de la sociedad mexicana.

\section{Conclusiones}

La figura de Frida Khalo constituye un referente de la cultura mexicana que, por sus logros a nivel artístico, trascendió en el ámbito de la cultura popular y de género. En opinión de la artista visual Dalia Martínez, Frida contribuyó a revalorizar lo mexicano. Es un estandarte: "un icono que se extiende en la cultura popular que permea todos los estratos, desde lo más comercial hasta la alta cultura". (Martínez, 2020)

Lasindustriasculturales, quetodoreducenaunusoinstrumental, la hantransformado en mercancía,con lo cual pierdesusignificaciónhistórica, artísticaygenéricaal constituirse enmerofetichedel consumismo delacultura demasas quecirculaentodotipo desouvenirs comopostales, camisetas, vasostequileros, botones, pulseras, bolsos, delantales, etcétera.

De ahí que Mattel utilice su imagen para comercializar a Barbie. El lanzamiento de la muñeca como Frida ha sido objeto de controversia legal debido a que las herederas de la creadoranoautorizaronsucirculación(Mateos-Vega,2018;Sierra,2018;SierrayDíaz,2018). De hecho, un juez prohibió la venta de la muñeca en México, al reconocer que la familia de Frida es la única propietaria de los derechos de su imagen.(Clarín, 2018; Zapata, 2018)

En la década de 1970 del siglo XX, Frida despertó el interés cultural del feminismo de la época por sus narrativas visuales, que en la actualidad pueden leerse como temáticas de género. La historiadora Laura González Matute considera que el fenómeno de "Frida" o "Fridomanía" es y será un tema complejo:

"La artista seguirá siendo un mito y un ejemplo para algunas mujeres de la actualidad [es un mito y una leyenda] porque un mito es algo que se tiene en una cultura que se repite y una leyenda es algo que sucedió pero que continúa vigente, sigue impactando y trascendió". (González, 2015) 
Entonces, puede decirse que Frida se encuentra en ambas. Lo cierto es que la fama de Frida trascendió fronteras y su imagen se globalizó, por lo que las industrias culturales vieron en ella un filón que han explotado hasta la saciedad, con lo cual se banaliza su legado cultural y artístico.

\section{Referencias}

Notimex. (3 de diciembre de 2016). Barbie al estilo Andy Warhol para esta navidad. Expansión. Recuperado de http://expansion.mx/lifestyle/2015/12/03/barbie-yandy-warhol-traeran-el-pop-art-esta-navidad [Consultado 30 abril 2016].

Barbosa, A. (2016). La valoración de la obra de arte. ASRI. Arte y Sociedad, Revista de Investigación, 10, pp. 1-12. Recuperado de: https://dialnet.unirioja.es/servlet/articulo?codigo $=5410554$

Barragán, A. (13 de julio de 2017). La muerte de Frida Kahlo el nacimiento de un icono pop. El País. Recuperado de https://elpais.com/cultura/2017/07/13/actualidad/1499954384_298167.html

Breton, A. (1997). Antología (1913-1966). México: Siglo XXI Editores.

Bourdieu, P. (1990). Sociología y cultura. México : Grijalbo-Consejo Nacional para la Cultura y las Artes.

Bourdieu. (1991). El sentido práctico. Madrid: Taurus.

Carreón Blaine, E. (2013). Barbie en Palenque, o la manufactura de lo intangible. Anales

del Instituto de Investigaciones Estéticas, 1(1), pp. 65-91. https://doi.org/10.22201/ iie.18703062e.2013.1.2488

CNN Español. (24 abril de 2018). La Barbie de Frida Kahlo no se venderá en México por orden de un juez. CNN Latinoamérica. Recuperado de https://cnnespanol. cnn.com/2018/04/23/la-barbie-de-frida-kahlo-no-se-vendera-en-mexico-pororden-de-un-juez/ 
González, L. (11 de junio de 2015). ¿Por qué Frida Khalo es una leyenda? El Universal. Recuperado de https://www.eluniversal.com.mx/articulo/cultura/artes-visuales/2015/06/11/por-que-frida-kahlo-es-una-leyenda\#: :text=Para\%20Gonz\%C3\%A1lez\%20Matute\%2C\%20Frida\%20es,y\%20Frida\%20est\%C3\%A1\%20 en\%20ambas.

Herrera, H. (2004). Frida: Una biografía de Frida Kahlo. México: Editorial Diana.

Horkheimer, M. y Adorno, T. W. (2009 [1944-1947]). Dialéctica de la llustración. Fragmentos Filosóficos. Madrid: Trotta.

Kahlo, F. (1935). Unos cuantos piquetitos. En Fernández Villaverde, M. (8 de marzo de 2016). El cuadro del día. Harte con Hache. Tumblr. Recuperado de https://www. elcuadrodeldia.com/post/140684105213/frida-kahlo-unos-cuantos-piquetitos-1935

Kahlo, F. (1940). Autorretrato de pelona. En Fernández Villaverde, M. (28 de febrero de 2016). El cuadro del día. Harte con Hache. Tumblr. Recuperado de https:// www.elcuadrodeldia.com/post/140143895658/frida-kahlo-autorretrato-de-pelona-1940-\%C3\%B3leo

La Razón Online. (20 de abril de 2018). Prohíben vender en México muñecas Barbies con imagen de Frida Kahlo. Razón. Recuperado de https://www.razon.com.mx/ entretenimiento/prohiben-vender-en-mexico-la-muneca-barbie-frida-kahlo/

Lammers, G. (3 de diciembre de 2016). "Sólo un museo puede canonizar a un artista": Spiegler. El Universal. Recuperado de https://www.eluniversal.com.mx/articulo/ cultura/artes-visuales/2016/12/3/solo-un-museo-puede-canonizar-un-artista-spiegler

Lipovetsky, G. y Serroy, J. (2015). La estetización del mundo. Vivir en la época del capitalismo artístico. Barcelona: Editorial Anagrama. 
Lozano, L. (2007). Frida Kahlo. Una relectura para conocer el universo estético de la pintora. En Frida. Edición conmemorativa: 100 años del nacimiento de Frida Kahlo (pp. 18-170). México: Oceano-Landucci.

Marciales, L. (9 de marzo de 2019). Cada tres segundos se vende una muñeca Barbie alrededor del mundo. La República. Recuperado de https://www.larepublica.co/ ocio/cada-tres-segundos-se-vende-una-muneca-barbie-al-rededor-del-mundo-2837522

Martínez, D. (6 de julio de 2020). Desde Disney hasta Madonna, Frida Kahlo marca la cultura pop. El Universal. Recuperado de https://www.eluniversal.com.mx/espectaculos/desde-disney-hasta-madonna-frida-kahlo-ha-marcado-la-cultura-pop

Mateos-Vega, M. y Flores, A. (07 marzo de 2018). Kahlo es dignidad no mercancía: Jesusa. La Jornada. Recuperado de https://www.jornada.com.mx/2018/03/07/cultura/a03n1cul

Mateos-Vega, M. (7 de marzo de 2018). Lanzan Barbie inspirada en la pintora mexicana. La Jornada. Recuperado de https://www.jornada.com.mx/2018/03/07/cultura/ a03n2cul

Mato, D. (2007). Todas las industrias son culturales: crítica de la idea de "industrias culturales" y nuevas posibilidades de investigación. Nueva época, 8, pp. 131-153. https://doi.org/10.32870/cys.v0i8.3833

Moore, H. (1 de octubre de 2015). Why Warhol painted Barbie. BBC News. Recuperado de https://www.bbc.com/news/magazine-34407991

Ramírez Peña, N.V. (2016). Noções de androginia na obra da artista "Frida Kahlo". Revell, Revista de Estudos Literários da UEMS, 2(13), pp. 158-176. Recuperado de https:// periodicosonline.uems.br/index.php/REV/article/view/1131 
Rico, A. (1992). Frida Kahlo. Fantasía de un cuerpo herido. México: Plaza y Valdés Editores.

Riddick, K. (2001). Barbie: The Image of Us All. X Roads. Recuperado de: http://xroads. virginia.edu/ class/am483_95/projects/barbie/barb.html

Sierra, S. y Díaz, J. (7 de marzo de 2018). Familia Kahlo no autorizó Barbie. El Universal. Recuperado de https://www.eluniversal.com.mx/cultura/familia-kahlo-no-autorizo-imagen-de-frida-en-barbie

Sierra, S. (9 de marzo de 2018). Nunca le dimos la imagen a Frida Kahlo Co. El Universal. Recuperado de: https://www.eluniversal.com.mx/cultura/artes-visuales/nuncale-dimos-la-imagen-frida-kahlo-co-herederas

Clarín. (20 de abril 2018). Sin el espíritu de la célebre artista. La heredera de Frida Kahlo le ganó a Barbie y la muñeca ya no podrá venderse. Clarín. Recuperado de https://www.clarin.com/sociedad/barbie-frida-khalo-herederas-venderse_0_SyUFxF83z.html

Weissman, K. (1999). Barbie. The Icon, The Image, The Ideal. An Analytical Interpretation of the Barbie Doll in Popular Culture. EE. UU.: Universal Publishers.

Webmaster. (7 de marzo de 2018). Lanzan Barbie de Frida y Lorena. Reforma. Recuperado de https://laprensademonclova.com/2018/03/08/lanzan-barbie-de-frida-y-lorena/

Zapata, B. (23 de abril de 2018). La Barbie de Frida Kahlo no se venderá en México por orden de un juez. CNN Latinoamérica. Recuperado de https://cnnespanol. cnn.com/2018/04/23/la-barbie-de-frida-kahlo-no-se-vendera-en-mexico-pororden-de-un-juez/ 